\title{
Relationship of Temple Infrastructure with Devotees' Spiritual Experience with Special Reference to Arulmigu Subramanya Swamy Temple, Kundrathur, Chennai
}

\author{
B.Eswaran, K.Anandanatarajan
}

\begin{abstract}
Spiritual Marketing Is The Ability To Articulate \& Convey The Authentic Beliefs Around A Service, Product Or Brand Transparently, Consciously And With The End Users Benefit In Mind. This Study Is Related To Spiritual Marketing And Trying To Find Out The Relationship of Temple Infrastructure With Devotees' Spiritual Experience Who Does Darshan At Arulmigu Subramanya Swamy Temple, Kundrathur, Chennai. As The Researches Are Very Primitive In The Area Of Spiritual Marketing, The Variables Were Identified Through Literature Survey And By Conducting A Focus Group Interview With The Subject Experts, Temple Priests, Hindu Religious And Charitable Endowment Department Officials And Few Devotees. The Questionnaire Was Formulated And Pilot Study Was Conducted Using 39 Samples. Then Reliability Test Was Done Using Cronbach's Alpha. Primary Data Was Collected From The Devotees Who Does Darshan At Arulmigu Subramanya Swamy Temple Through Simple Random Sampling For Infinite Population. Using Cochran's Formula For Infinite Population, The Sample Size Was Determined As 384. The Primary Data Was Collected And Analysed Using Various Tests Such As Independent Sample T Test, Correlation, And Anova. Finally, Through This Research It Was Identified That Temple Infrastructure Is Not Related To The Devotees' Overall Spiritual Experience.
\end{abstract}

Keywords: Beliefs, Spiritual experience, Spiritual Marketing, Temple infrastructure.

\section{INTRODUCTION}

Spiritual Marketing is the ability to articulate \& convey the authentic beliefs around a service, product or brand transparently, consciously and with the end users benefit in mind. Spiritual marketing is being done by various religious institutions irrespective of the religion. They offer various goods and services for the wellbeing of the human beings. Our study majorly focusses on the hindu religion and its one of the temples i.e. Arulmigu Subramanya Swamy temple, Kundrathur. The temple offers various services such as Archanai, tonsuring, Ear boring, Marriages etc.

Manuscript published on November 30, 2019.

* Correspondence Author

B.Eswaran*, Assistant Professor, Department of Business Administration, Alpha Arts and Science college, Porur, Chennai, India.

Dr.K.Anandanatarajan, Associate Professor at Department of Business Administration, Annamalai University, Chidambaram, India.

The Authors. Published by Blue Eyes Intelligence Engineering and Sciences Publication (BEIESP). This is an open access article under the CC-BY-NC-ND license http://creativecommons.org/licenses/by-nc-nd/4.0/
The temple infrastructure consists of Space for performing marriages, statues, Annadhana Mandapam, Temple tank (Saravana Poigai), Book stall, Prasadham Stall, Chariot, Hundi, Sthala Vruksha and other trees, flagstaff (Kodimaram) and balipeedam. This study tries to find out the relationship of temple infrastructure with devotees' spiritual experience who does darshan in this temple.

\section{LITERATURE REVIEW}

Banerjee (2014), emphasized that the standard of accommodation and quality of food available in a destination is an important component of the impression and image it creates in the minds of the traveller.

Sudhir Kale (2006), gave a working definition of spirituality and preliminary guidelines to kick-start research and dialogue in the area of spiritual marketing. It is argued that spiritual utility urgently needs to be incorporated along with other utilities when considering product benefits.

Shika Makkar et al (2017), conducted a study on marketing of products sold by spiritual organizations. A survey was conducted among female youth in Delhi to study whether spiritual beliefs of consumers and loyalty towards these spiritual organizations affects the buying pattern or not. Researchers draw the conclusion that the main reason for sale of the products are the product quality and its branding as organic and a promise of healthier lifestyle. It's the healthier lifestyle, more than the product that the consumer is buying.

Banerjee (2014), emphasized that the standard of accommodation and quality of food available in a destination is an important component of the impression and image it creates in the minds of the traveller.

Many studies (e.g. Lewis, 1987; Crompton and Love, 1995; O'Neill et al., 1999; Baker and Crompton, 2000; Nowacki, 2005; Hassan \& Iankova, 2012), have considered amenities as basic or subsidiary factor of a tourist destination and these factors are necessary for offering a satisfactory tourist experience.

Researchers and marketers tend to be in consensus about the importance of image for a destination's viability and success in tourism, because the perception of destination image relates to decision-making and sales of tourist products and services (Jenkins, 1999; Tasci \& Gartner, 2007). 


\section{Relationship of Temple Infrastructure with Devotees' Spiritual Experience with Special Reference to Arulmigu Subramanya Swamy Temple, Kundrathur, Chennai}

Tasci and Gartner (2007), did research and found out that the destination image is the total sum of beliefs, convictions and emotional attachment that individuals have of a destination that is, the cognitive/perceptual and affective.

As the researches are very primitive in the area of spiritual marketing, the variables were identified through literature surveys and by conducting a focus group interview with the subject experts, temple priests, Hindu religious and charitable endowment department officials and few devotees.

\section{MEANING OF THE VARIABLES}

\begin{tabular}{|c|c|c|}
\hline S.NO & VARIABLES & MEANING \\
\hline 1 & $\begin{array}{l}\text { Space for performing } \\
\text { marriages }\end{array}$ & $\begin{array}{l}\text { Space where marriages are } \\
\text { performed }\end{array}$ \\
\hline 2 & $\begin{array}{ll}\text { Divine Beauty of } \\
\text { Sculptures and statues }\end{array}$ & $\begin{array}{l}\text { The divine beauty of various } \\
\text { sculptures and statues in the } \\
\text { temple }\end{array}$ \\
\hline 3 & Annadhana Mandapam & $\begin{array}{l}\text { It is a part of a temple that is used } \\
\text { as dining hall where food is served } \\
\text { at free of cost. }\end{array}$ \\
\hline 4 & $\begin{array}{l}\text { Temple tank (Saravana } \\
\text { Poigai) }\end{array}$ & $\begin{array}{l}\text { Temple tanks are wells or } \\
\text { reservoirs built as part of the } \\
\text { temple complex for bathing or } \\
\text { washing legs before getting into } \\
\text { the temple. }\end{array}$ \\
\hline 5 & Book stall & $\begin{array}{l}\text { The quality of the book stall in } \\
\text { terms of selling variety of spiritual } \\
\text { books }\end{array}$ \\
\hline 6 & Prasadham Stall & $\begin{array}{l}\text { It is a stall where food items are } \\
\text { sold after it was shown or offered } \\
\text { to the statue at sanctum sanctorum }\end{array}$ \\
\hline 7 & Chariot & $\begin{array}{l}\text { Wooden chariot where God / } \\
\text { Goddess would be placed and the } \\
\text { chariot is dragged by devotees as } \\
\text { the part of their prayers }\end{array}$ \\
\hline 8 & Hundi & $\begin{array}{l}\text { Hundi, where money is offered } \\
\text { into it by devotees as a part of } \\
\text { one's prayer or for celebrating the } \\
\text { festivals of the temple }\end{array}$ \\
\hline 9 & $\begin{array}{l}\text { Sthala Vruksha and other } \\
\text { trees }\end{array}$ & $\begin{array}{l}\text { Sthala Vriksha or Sthala } \\
\text { Vruksham is a monumental tree } \\
\text { that is indigenous to every } \\
\text { historical Hindu temple }\end{array}$ \\
\hline 10 & Toilet facilities & - \\
\hline 11 & Temple tower & - \\
\hline 12 & Artha Mandapam & $\begin{array}{l}\text { Intermediary space between the } \\
\text { temple exterior and the sanctum } \\
\text { sanctorum }\end{array}$ \\
\hline 13 & Kodimaram & Flagstaff \\
\hline
\end{tabular}

\section{RESEARCH OBJECTIVES}

1. To find out the relationship of temple infrastructure with devotees' spiritual experience.

2. To find out which infrastructural facilities give good spiritual experience.

\section{RESEARCH HYPOTHESIS}

Ho 1: There is no significant Relationship between the sufficiency of the place for performing marriages and overall spiritual experience.

Ho 2: There is no significant Relationship between beauty of the statues and overall spiritual experience.

Ho 3: There is no significant Relationship between Annadhana Mandapam in terms of size and seating arrangement with overall spiritual experience.
Ho 4: There is no significant Relationship between the quality of book stall and overall spiritual experience.

Ho 5: There is no significant Relationship between the quality of Prasadhams stall and overall spiritual experience.

Ho 6: There is no significant Relationship between the beauty of the Chariot and overall spiritual experience.

Ho 7: There is no significant Relationship between sufficient number of Hundi and overall spiritual experience.

Ho 8: There is no significant Relationship between temple tank (saravana poigai) and overall spiritual experience.

Ho 9: There is no significant Relationship between Sthala Vruksha and overall spiritual experience.

Ho 10: There is no significant Relationship between the beauty of temple tower and overall spiritual experience.

Ho 11: There is no significant Relationship between beauty of Artha Mandapam and overall spiritual experience.

Ho 12: There is no significant Relationship between the beauty of kodimaram (Flagstaff) and overall spiritual experience.

Ho 13: There is no significant Relationship between toilet facilities and overall spiritual experience.

Ho 14: There is no significant difference in gender on overall spiritual experience.

Ho 15: There is no significant relationship between age and overall spiritual experience.

Ho 16: There is no significant difference in the place they are coming from, on overall spiritual experience.

Ho 17: There is no significant relationship between frequency of visit and overall spiritual experience.

\section{RESEARCH METHODOLOGY}

The research method used in this study is descriptive research. The Questionnaire was formulated and pilot study was conducted using 39 samples. Then reliability test was done. Primary data was collected from the devotees who does darshan at Arulmigu Subramanya Swamy temple through simple random sampling for infinite population. Using Cochran's formula for infinite population, the sample size was determined as 384

\section{Cochran's Formula}

$\mathrm{SS}=\mathrm{Z}^{\wedge} 2$ (p) (1-p) / $\mathrm{C}^{\wedge} 2$

SS - Sample size

$\mathbf{Z}$ - Critical value of desired confidence level

$\mathbf{p}$ - the estimated proportion of an attribute that is present in the population

C - Desired level of precision

$\mathrm{SS}=(1.96) \wedge 2(0.5)(0.5) /(0.05) \wedge 2=384.16$

\section{DATA ANALYSIS \& INTERPRETATION}

The data was fed in SPSS and analysis was done using it

\section{A. Reliability test}

The pilot study was done and 39 samples were collected (i.e.10\% of the sample size $=38.4$ ). 
This data was used to check the reliability of the questionnaire. The Cronbach's alpha value is 0.883 . As the value is greater than 0.70 , the questionnaire is highly reliable.

Case Processing Summary
\begin{tabular}{|ll|l|l|}
\hline & N & $\%$ \\
\hline \multirow{3}{*}{ Cases } & Valid & 39 & 100.0 \\
& Excluded & 0 & 0 \\
& Total & 39 & 100.0 \\
\hline
\end{tabular}

\section{Reliability Statistics}

\section{Cronbach's Alpha $\mathrm{N}$ of Items}

\begin{tabular}{l|l}
\hline 883 & 13 \\
\hline
\end{tabular}

\section{B. Tables \& Charts}

Table 1

\begin{tabular}{|l|l|l|l|}
\hline S.No & Gender & Frequency & Percentage \\
\hline 1 & Male & 203 & 52.9 \\
\hline 2 & Female & 181 & 47.1 \\
\hline & Total & 384 & 100 \\
\hline
\end{tabular}

\section{Chart 1}

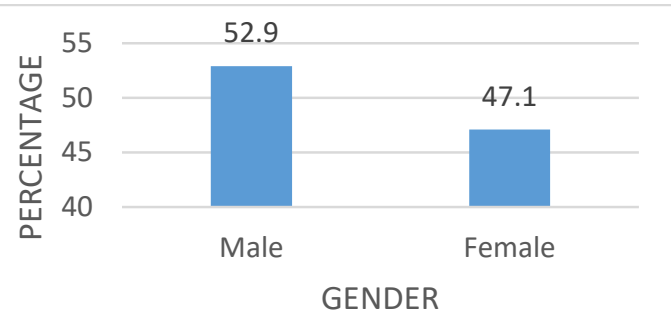

Table 2

\begin{tabular}{|l|l|l|l|}
\hline S.no & Place from & Frequency & Percentage \\
\hline 1 & Kundrathur & 231 & 60.2 \\
\hline 2 & $\begin{array}{l}\text { Nearby } \\
\text { Kundrathur }\end{array}$ & 135 & 35.2 \\
\hline 3 & Other places & 18 & 4.7 \\
\hline
\end{tabular}

Chart 2

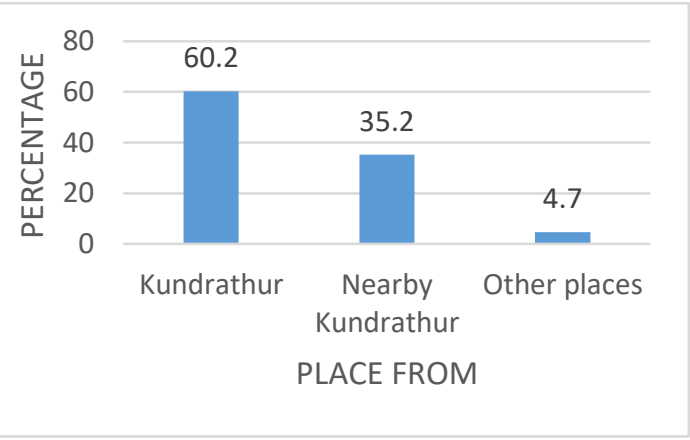

In the total 384 respondents, $60.2 \%$ of respondents are from Kundrathur, $35.2 \%$ of respondents are from nearby Kundrathur \& 4.7\% respondents are from other places.

\section{Independent sample t test}

An independent samples t-test was conducted to compare the devotees' overall spiritual experience between male and female gender (Note: Hypothesis number 14)

In the total 384 respondents, $52.86 \%$ are male $\& 47.14 \%$ are female.

Table 3

Group Statistics

\begin{tabular}{|l|c|c|c|c|c|}
\hline & Gender & N & Mean & $\begin{array}{c}\text { Std. } \\
\text { Deviation }\end{array}$ & $\begin{array}{c}\text { Std. Error } \\
\text { mean }\end{array}$ \\
\hline overall_exp & male & 203 & 87.05 & 7.111 & -499 \\
& female & 181 & 86.24 & 7.634 & .567 \\
\hline
\end{tabular}

Table 4

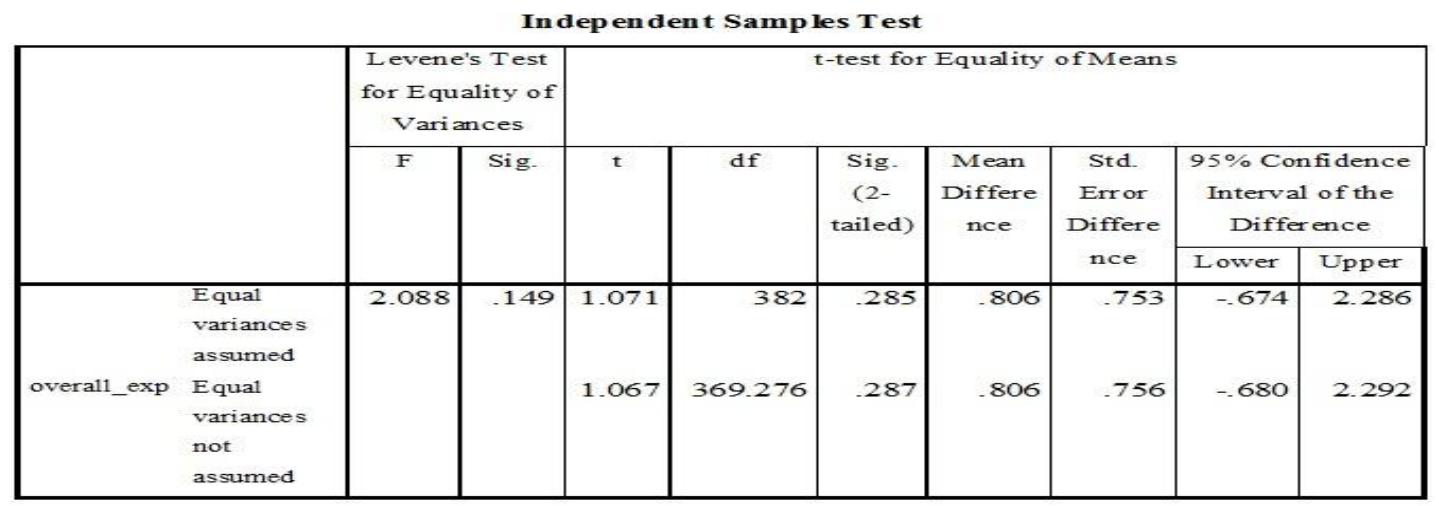

There was not a significant difference in the devotees' over all spiritual experience scores for male $(\mathrm{M}=87.05$, $\mathrm{SD}=7.111)$ and female gender $(\mathrm{M}=86.24, \mathrm{SD}=7.634)$ conditions; $\mathrm{t}(382)=1.071, \mathrm{p}=0.285)$.

\section{Analysis of Variance}

A One - way ANOVA was conducted to compare the effect of place on devotees' over all spiritual experience (Note: Hypothesis number 16) 


\section{Relationship of Temple Infrastructure with Devotees' Spiritual Experience with Special Reference to Arulmigu Subramanya Swamy Temple, Kundrathur, Chennai}

Table 5

ANOVA

overa II_exp
\begin{tabular}{|c|c|c|c|c|c|}
\hline & $\begin{array}{c}\text { Sum of } \\
\text { Squares }\end{array}$ & df & $\begin{array}{c}\text { Mean } \\
\text { Square }\end{array}$ & F & Sig. \\
\hline Between Groups & 21.797 & 2 & 10.898 & .200 & .819 \\
Within Groups & 20745.201 & 381 & 54.449 & & \\
Tota1 & 20766.997 & 383 & & & \\
\hline
\end{tabular}

An Analysis of Variance showed that the effect of place on devotees' over all spiritual experience was not significant, $F(2,381)=0.200, \mathrm{p}=0.819$.
Spearman's Rank correlation was done to check whether there are any significant relationships between the below said variables and overall spiritual experience.

\section{E. Correlation Analysis}

\begin{tabular}{|c|c|c|c|c|}
\hline Variable & p value & $\begin{array}{l}\text { Spearman's } \\
\text { correlation } \\
\text { coefficient }\end{array}$ & Result & Hypothesis number \\
\hline Age & 0.097 & 0.085 & $\begin{array}{l}\text { Based on the results, age is not related to the } \\
\text { overall spiritual experience, } \rho=0.085, p>.05\end{array}$ & Ho 15 \\
\hline Frequency of visit & 0.788 & 0.014 & $\begin{array}{l}\text { Based on the results, frequency of visit is not } \\
\text { related to the overall spiritual experience, } \rho= \\
0.014, p>.05\end{array}$ & Ho 17 \\
\hline $\begin{array}{l}\text { Space for performing } \\
\text { marriages }\end{array}$ & 0.697 & 0.020 & $\begin{array}{l}\text { Based on the results, the space for performing } \\
\text { marriages is not related to the overall spiritual } \\
\text { experience, } \rho=0.020, p>.05\end{array}$ & Ho 1 \\
\hline Beauty of the statues & 0.149 & 0.074 & $\begin{array}{l}\text { Based on the results, the beauty of statues is not } \\
\text { related to the overall spiritual experience, } \rho= \\
0.074, p>.05\end{array}$ & Ho 2 \\
\hline Annadhana Mandapam & 0.342 & 0.049 & $\begin{array}{l}\text { Based on the results, the Annadhana Mandapam } \\
\text { is not related to the overall spiritual experience, } \rho \\
=0.049, \mathrm{p}>.05\end{array}$ & Ho 3 \\
\hline Book stall & 0.124 & 0.079 & $\begin{array}{l}\text { Based on the results, book stall is not related to } \\
\text { the overall spiritual experience, } \rho=0.079, p> \\
.05\end{array}$ & Ho 4 \\
\hline Prasadham stall & 0.686 & 0.021 & $\begin{array}{l}\text { Based on the results, the Prasadham stall is not } \\
\text { related to the overall spiritual experience, } \rho= \\
0.021, p>.05\end{array}$ & Ho 5 \\
\hline Beauty of the Chariot & 0.289 & 0.054 & $\begin{array}{l}\text { Based on the results, the beauty of the chariot is } \\
\text { not related to the overall spiritual experience, } \rho= \\
0.054, p>.05\end{array}$ & Ho 6 \\
\hline $\begin{array}{l}\text { Sufficient number of } \\
\text { Hundi }\end{array}$ & 0.636 & 0.024 & $\begin{array}{l}\text { Based on the results, the sufficient number of } \\
\text { hundi is not related to the overall spiritual } \\
\text { experience, } \rho=0.024, p>.05\end{array}$ & Ho 7 \\
\hline $\begin{array}{l}\text { Cleanliness of Temple } \\
\text { tank (saravana poigai) }\end{array}$ & 0.385 & 0.044 & $\begin{array}{l}\text { Based on the results, the cleanliness of temple } \\
\text { tank is not related to the overall spiritual } \\
\text { experience, } \rho=0.044, p>.05\end{array}$ & Ho 8 \\
\hline Sthala Vruksha & 0.766 & 0.015 & $\begin{array}{l}\text { Based on the results, the Sthala Vruksha is not } \\
\text { related to the overall spiritual experience, } \rho= \\
0.015, p>.05\end{array}$ & Ho 9 \\
\hline Beauty of temple tower & 0.494 & 0.035 & $\begin{array}{l}\text { Based on the results, beauty of the temple tower } \\
\text { is not related to the overall spiritual experience, } \rho \\
=0.035, \mathrm{p}>.05\end{array}$ & Но 10 \\
\hline $\begin{array}{l}\text { Beauty of Artha } \\
\text { Mandapam }\end{array}$ & 0.907 & 0.006 & $\begin{array}{l}\text { Based on the results, the Beauty of Artha } \\
\text { Mandapam is not related to the overall spiritual } \\
\text { experience, } \rho=0.006, p>.05\end{array}$ & Ho 11 \\
\hline $\begin{array}{l}\text { Beauty of kodimaram } \\
\text { (Flagstaff) }\end{array}$ & 0.570 & 0.029 & $\begin{array}{l}\text { Based on the results, the Beauty of kodimaram is } \\
\text { not related to the overall spiritual experience, } \rho= \\
0.029, p>.05\end{array}$ & Но 12 \\
\hline Toilet facilities & 0.062 & 0.095 & $\begin{array}{l}\text { Based on the results, the toilet facility is not } \\
\text { related to the overall spiritual experience, } \rho= \\
0.095, p>.05\end{array}$ & Но 13 \\
\hline
\end{tabular}




\section{CONCLUSION}

This study concludes that the temple infrastructure is not related to the devotees' overall spiritual experience and the overall spiritual experience doesn't change with the changes in the gender and the place of the devotees.

\section{REFERENCES}

1. Andrew Lepp, Heather Gibson, Charles Lane.(2011) "Image and perceived risk: A study of Uganda and its official tourism website" Tourism Management, Volume 32, Issue 3, June, pp 675-684

2. Baloglu, S. \&, K.W (1999). "A model of destination image formation, Annals of Tourism Research", 35 (4), 11-15.

3. Bigne E., Sánchez, M. I., \& Sánchez, J. (2001), "Tourism Image, Evaluation Variables and After Purchase Behaviour: InterRelationship", Tourism Management, 22(6), 607-616.

4. Boniface, B.G. and Cooper, C. (1994) The Geography of Travel and Tourism $\left(2^{\text {nd }}\right.$ edition $)$, Oxford: Butterworth-Heinemann

5. Bowie, D. and Chang, J. C. (2005) Tourist satisfaction: A view from a mixed international guided package tour, Journal of Vacation Marketing, 11(4) pp.303- 322.

6. Bramwell, B. (1998), User satisfaction and product development in urban tourism, Tourism Management, 19(1), 35 - 47.

7. Castro, C. B., Armario, E. M., \& Ruiz, D. M. (2007). The influence of market heterogeneity on the relationship between a destination's image and tourists' future behavior. Tourism Management, 28, 175-187.

8. Embacher, J., \&Buttle, F. (1989). "A repertory grid analysis of Austria's image as a summer vacation destination".Journal of Travel Research. Winter, 3-7.

9. Emilio Celottoab, Andrea Elleroa*, Paola Ferrettic, Conveying tourist ratings into an overall destination evaluation, Procedia - Social and Behavioral Sciences 188 (2015) $35-41$.

10. Fall, L.T. \& Knutson, B.J. (2001). "Personal values and media usefulness of mature travelers". Journal of Hospitality and Leisure Marketing, 8, 97-111.

11. Fyall, A., \& Leask, A. (2007). "Destination marketing: future issues strategic challenges. Tourism and Hospitality Research", 7(1), 50-63.

12. Gallarza, M. G., Saura, I. G., \& Garcia, H. C. (2002). Destination image: Towards a conceptual framework. Annals of Tourism Research, 29(1), 56-78.

13. Gallarza, M. G., and Saura, I. G. (2006). Value dimensions, perceived value, satisfaction and loyalty: an investigation of university students' travel behaviour. Tourism Management, 27, 437-452.

\section{AUTHORS PROFILE}

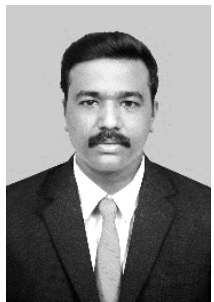

B.Eswaran, Research Scholar, Annamalai University, Chidambaram \& currently serving as an Assistan Professor, Department of Business Administration, Alpha Arts and Science college, Porur, Chennai. He completed his Under graduation in Biotechnology and MBA specialised in Marketing at Madurai Kamaraj University. He has cleared his UGC-NET in Management. He has completed his Post Graduate Programme in Business Analytics and Business Intelligence at Great Lakes Institute of Management\& Illinois Institute of Technology, USA. Currently he is pursuing his doctoral programme in Business Administration at Annamalai University Chidambaram. He may be reached at eswaran.faculty@gmail.com.

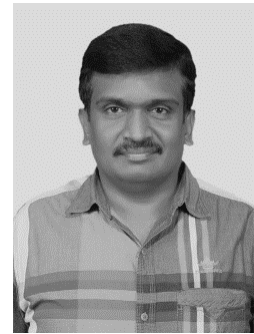

Dr.K.Anandanatarajan, is currently serving as Associate Professor at Department of Business Administration, Annamalai University, Chidambaram. He has 19 years of teaching experience. He has participated and presented his research papers in National \& International Seminars and conferences. He has contributed more than 45 research papers in National and International journals. He has produced 6 doctorates in management discipline. His areas of may be reached at professorkanand@gmail.com 